described in 1929 by Mawson from South Australia : Quart. Journ. Geol. Soc., 85, 613-623; and in 1946 by Clarke and Teichert from Western Australia : Amer. Journ. Sci., 244, 271-276), and that brecciation of the carbonate mud was not only caused by the growth of the algae themselves, but also by expansion (especially in the shallows) of ice forming periodically in the algae-infested lakes.

Department of Geology,

Allan F. Wilson.

UNIVERSITY OF WeSTERN Australia, NEDLANDS,

Western Australia.

28th February, 1951.

\title{
MICROPALAEONTOLOGICAL TECHNIQUE
}

SIR,--Just over a year ago, a method of breaking down shales for micropalaeontological study was mentioned in abstract in the Micropalaeontologist by Mr. N. M. Layne, jun. Quoting from the abstract, the details of the method are as follows:-

"First heat the sample on a gas plate or in an oven sufficiently to drive off the interstitial moisture. After it has cooled pour gasoline over it and allow to stand for about half an hour. Next decant the gasoline, and cover the sample with water."

Since reading of this method, I have carried out several experiments with it, using a slight variation in that the sample is dried again after the gasoline is decanted, and before the water is added. With this method, samples of extremely hard shale which normally take five to six hours to prepare by the normal repeated hydration and dehydration, are ready for microscopic examination within one hour. Pure sandstones are not affected by this method, but impure sandstones are found to break down, the speed of the reaction increasing with the proportion of argillaceous matter present.

I mention this process here because the Micropalaeontologist has a somewhat restricted circulation amongst general palaeontologists in England, and also because the applicability of the method goes well beyond the field of micropalaeontology into that of general palaeontology. In one of the experiments I was able to extract from an impure sandstone entire shells of macrofossils so cleanly that the internal and external details could be seen perfectly.

It would seem therefore that this method of breaking down samples could do much to speed up the work of palaeontologists, as well as lessen considerably the risk of damage to specimens whilst cleaning them mechanically.

LoBITOS, Peru.

A. J. KNIGHTS.

28th February, 1951.

Reference.-LAyne, N. M., A Proceedure for Shale Disintegration. The Micropolaeontologist, iv, No. 1, 1950.

\section{LINEATION IN HIGHLAND SCHISTS}

SIR,-In three short Notes recently published in the Geological Magazine, I have attempted to demonstrate a simple, and I feel useful, macroscopic way of looking at folded rocks. Applying this point of view in many parts of the Highlands, I have been impressed by the prevalence of $b$-lineations similar to those described in the Notes. It should perhaps be pointed out that my approach is more similar to that employed by Dr. F. Coles Phillips in his important pioneer work on the fabric of the Moine (Quart. Journ. Geol. Soc., xciii, 581-620) than might be evident at first sight. When it is realized that my text-figures represent profiles at right angles to the foldaxes, it will be appreciated that in my examples, as in those of Dr. Coles Phillips, there is a marked tendency for the micas at any rate to lie on a more 
or less well-marked girdle. The lineation is, of course, normal to the girdle. I am thus in whole-hearted agreement with Dr. Coles Phillips's conclusion that the fold-movements in the Highlands took place in planes normal to the dominant lineations. Indeed, away from the immediate neighbourhood of the great thrusts, the Cowal area is the only one where I have observed linear structures which are, apparently, nearly at right angles to the trend of the folds.

Many of the early workers believed the dominant fold-trend in the Highlands to be N.E.-S.W. This opinion appears to have been founded on the common occurrence of N.E.-S.W. directed outcrops, and of the abundance of lineations nearly normal to the strike of the Moine Thrust. Alpine and Fennoscandian examples of general-strikes nearly normal to fold-trends have been known for many years ; among Scottish examples, the Grantown and Kincraig Series in Mid-Strathspey, and the Fannich-Attadale Pelitic Belt in Ross-shire, can now be cited. Moreover, Dr. Coles Phillips's work, confirmed by my observations, indicates that the lineations have no genetic relationship to the Moine Thrust. Are we then to turn Highland structures through a right angle and regard the dominant fold-trend as being N.W.-S.E.?

All the trends shown on Dr. Coles Phillips's map (ibid., p. 594, fig. 5) are either W.N.W.-E.S.E. or N.W.-S.E, How far are these directions typical of the Highlands as a whole ? During the past three years I have been collecting measurements of $b$-lineations in an attempt to answer this question. Much work remains to be done, but the following provisional conclusions may be of interest. Approximately N.E.-S.W. trends seem to be characteristic of three main areas : (1) from Kintyre north-eastwards to beyond Fort William, and probably to Strathspey ; indeed it is even possible that this belt partly separates the N.W.-S.E. trend characteristic of Mid-Strathspey from the region, again with N.W.-S.E. trend, to the north of the Great Glen; (2) from Loch Lomond east-north-eastwards along the southern edge of the Highlands to Stonehaven; and (3) along the south coast of the Moray Firth. It is probable that a relatively small area with N.E.-S.W. trend is present immediately to the south and south-west of Loch Monar. The central part of the Grampians, from near Dalmally east-north-eastwards to Aberdeenshire, appears to be of great complexity ; it seems to consist of a series of great arcs convex towards the south-west. It may be remarked here that the Newer Granites appear to have but little influence on the general structural pattern.

Apart from south-east Sutherland, where there may have been mobilization in the migmatites, and the Loch Monar area mentioned above, the region to the north of the Great Glen seems to be relatively simple. The arcuate pattern recorded by Dr. Coles Phillips has been confirmed by my observations, and it is indeed probable that, to the west and south of Loch Eil, the trend may have swung round to a N.E.-S.W. direction. I had hoped that comparison of the structure patterns on either side of the Great Glen might throw light on Professor Kennedy's hypothesis of transcurrent faulting along that line. Unfortunately the data are not yet adequate ; immediately to the east-north-east of Fort Augustus the trend is N.W.-S.E. as it is in Glen Moriston on the other side of the Great Glen.

It is true that $I$ regard the sense of movement in Mid-Strathspey to have been towards the south-west, although I agree that the evidence is not altogether conclusive. Clockwise and anti-clockwise rotations may occur on the two limbs of a single fold, and therefore it is difficult to extrapolate the sense of movement observed macroscopically to larger scales. However, the complexity of Highland structure is so great that, even if I am correct in considering the movement throughout Mid-Strathspey to have been towards the south-west, it is still possible that to the north-west of the Great Glen an opposite sense prevailed.

Grant Institute of Geology,

Donald B. McInTyRe. UNIVERSITY OF EDINBURGH.

28th February, 1951. 